\title{
Low expression of PRKCDBP promoted cisplatin resistance in lung adenocarcinoma by DNMT1 and TNF- $\alpha$
}

\author{
JIALI FU $^{1 *}$, HUIXIN ZHOU $^{1 *}$, JIE CHEN $^{2}$ and YUMIN WANG ${ }^{1}$ \\ Departments of ${ }^{1}$ Laboratory Medicine and ${ }^{2}$ Intensive Care Unit, The First Affiliated Hospital of \\ Wenzhou Medical University, Wenzhou, Zhejiang 325027, P.R. China
}

Received April 1, 2020; Accepted July 9, 2020

DOI: 10.3892/or.2020.7721

\begin{abstract}
The aim of the present study was to explore the mechanism of protein kinase $\mathrm{C}$ delta binding protein (PRKCDBP) promoting cisplatin resistance in lung adenocarcinoma (LAD). The PRKCDBP expression level was herein detected by reverse transcription-quantitative polymerase chain reaction (RT-qPCR). We overexpressed PRKCDBP and tumor necrosis factor- $\alpha$ (TNF- $\alpha$ ) in A549/DDP cell line, DNMT1 in A549 cells and siRNA TNF- $\alpha$ in A549 cells with lentivirus-mediated technique, and then, analyzed their biological diversification. The results showed a significantly lower expression level of PRKCDBP was lowly expressed in the A549/DDP cell line and LAD tissues than that in A549 cells and adjacent cancer tissues $(\mathrm{P}<0.05$ and $\mathrm{P}<0.01)$, while the DNMT1 mRNA level was remarkably increased $(\mathrm{P}=0.000)$ and the promoter of PRKCDBP was hypermethylated in the A549/DDP cell line. Additionally, DNMT1 mRNA level in cisplatin-insensitive group was markedly higher than that in cisplatin-sensitive group $(\mathrm{t}=7.233, \mathrm{P}<0.0001)$, while PRKCDBP mRNA level in cisplatin insensitive group was notably lower than that in cisplatin-sensitive group $(\mathrm{t}=8.784, \mathrm{P}<0.0001)$. The results showed that PRKCDBP mRNA level was significantly elevated following treatment with $5 \mu \mathrm{M}$ decitabine for $24 \mathrm{~h}$ $(\mathrm{P}<0.0001)$, while the DNMT1 mRNA level was notably reduced $(\mathrm{P}=0.000)$. When PRKCDBP was overexpressed, the DNMT1 mRNA level was markedly decreased $(\mathrm{P}=0.007)$, the rate of proliferation $(\mathrm{P}<0.05$ or $\mathrm{P}<0.01)$, IC50 of cisplatin
\end{abstract}

Correspondence to: Dr Jie Chen, Department of Intensive Care Unit, The First Affiliated Hospital of Wenzhou Medical University, Wenzhou, Zhejiang 325027, P.R. China

E-mail: chenjie991300@163.com

Dr Yumin Wang, Department of Laboratory Medicine, The First Affiliated Hospital of Wenzhou Medical University, Wenzhou Zhejiang 325027, P.R. China

E-mail:wym0577@163.com

*Contributed equally

Key words: lung adenocarcinomas, PRKCDBP, cisplatin resistance, DNMT1, TNF- $\alpha$
$(\mathrm{P}<0.001), \mathrm{G} 2 / \mathrm{M}$ phase and $\mathrm{S}$ phase cells were obviously reduced $(\mathrm{P}<0.001)$, while $\mathrm{G} 0 / \mathrm{G} 1$ phase cells, apoptosis $(\mathrm{P}<0.001)$ distinctly increased, but migration ability did not significantly change. TNF- $\alpha$ overexpression resulted in an increase of PRKCDBP mRNA level $(\mathrm{P}<0.001)$, while TNF- $\alpha$ siRNA led to PRKCDBP mRNA level distinctly reduced $(\mathrm{P}<0.001)$. Overexpression of DNMT1 improved IC50 in A549 cells. Thus, findings of the present study ascertained the promoter of PRKCDBP was hypermethylated in A549/DDP cells. In conclusion, low expression of PRKCDBP promoted cisplatin resistance in LAD by DNMT1 and TNF- $\alpha$.

\section{Introduction}

Lung cancer is the leading cause of death from cancer worldwide, with the highest incidence and mortality among different types of cancers (1). Lung adenocarcinoma (LAD) is the most common type of non-small cell lung cancer (NSCLC), accounting for $40 \%$ of lung cancer (2). Although some targeted and immunological drugs have been presented, cisplatin-based combination chemotherapy plays a significant role in comprehensive treatment programs of lung cancer (3). With the large-scale application of cisplatin drugs, tumor cells become resistant to those drugs, and the therapeutic effects of chemotherapy have markedly reduced. (4). A previous study demonstrated that long-term use of cisplatin drugs in patients with lung cancer lead to a relapse rate of more than $60 \%$, while the remission rate of relapsed lung cancer chemotherapy drugs was less than $30 \%$ (5). The remission rate of the current chemotherapy regimen for lung cancer was only $30-40 \%$, and the five-year survival rate was lower than $15 \%$ in patients with advanced LAD (6). Once the cancer cells are resistant to cisplatin, they may be resistant to various first-line chemotherapeutic drugs, such as doxorubicin, vinblastine, fluorouracil, and mitomycin (7). Therefore, it is imperative to identify specific molecular targets and biomarkers related to cisplatin resistance in LAD to reverse resistance to cisplatin. Previous findings have shown that cisplatin is a non-specific cell cycle cytotoxic drug which plays a role mainly by inhibiting DNA synthesis (8) and inducing apoptosis (9) of tumor cells. The resistance mechanism of cisplatin is extremely complex and involves multiple genes, proteins and several pathways and is related to some mechanisms, such as reduced drug uptake, increased drug inactivation, and increased DNA 
damage repair (8-12). Despite progress in the field of genomics and proteomics, the resistance mechanism of cisplatin has remained elusive.

The NSCLC A549 cell line is sensitive to cisplatin. The A549 cell is gradually induced by the cisplatin drug to produce A549/DDP, which can maintain stable drug resistance to cisplatin. In a previous study, we used high-throughput microarray technology to compare LAD cisplatin-resistant A549/DDP cell and cisplatin-sensitive A549 cell, and obtained differential mRNA expression profiles of LAD cisplatin-resistant (13). Use of mRNA microarray and reverse transcription-quantitative polymerase chain reaction RT-PCR (RT-qPCR) demonstrated that protein kinase $\mathrm{C}$ delta binding protein (PRKCDBP) is an mRNA molecule with the length of 1,039 bp which is downregulated in A549/DDP. PRKCDBP is genetically and epigenetically altered in several human malignancies and is a tumor suppressor gene, and its low expression levels may be associated with a high degree of methylation of PRKCDBP (14-17). Thus, it was found that low expression of PRKCDBP could play a key role in LAD resistance to cisplatin.

The role of PRKCDBP in LAD resistance to cisplatin is not well understood. In the present study, we overexpressed PRKCDBP in A549/DDP by lentiviral technology to determine the underlying mechanism.

\section{Materials and methods}

Human LAD tissue specimen. Patients with LAD were recruited from the First Affiliated Hospital of Wenzhou Medical University (Wenzhou, China) from May 2010 to July 2015. The inclusion criterion was that patients with primary LAD were in stages IIIB to IV. The first-line chemotherapy was cisplatin $\left(25 \mathrm{mg} / \mathrm{m}^{2}\right)$ in the first 1 to 3 days, and combined with gemcitabine $\left(1,000 \mathrm{mg} / \mathrm{m}^{2}\right)$ or paclitaxel $\left(80 \mathrm{mg} / \mathrm{m}^{2}\right)$ on the 1 st and 8 th days. A cycle of chemotherapy was considered 21 days and each patient was treated for 3 to 4 cycles. According to medical imaging examinations [including computed tomography (CT), magnetic resonance imaging (MRI)] and the results of serum lung tumor markers and response evaluation criteria in solid tumor (RECIST) standards, the patients were grouped into the 'cisplatin sensitive group' (complete remission + partial remission) and 'cisplatin insensitive group' (progress). The specimens, which included 25 cisplatin-sensitive and 32 cisplatin-insensitive specimens, were strictly identified by the Department of Pathology (Wenzhou, China). The study was approved by the Ethics Committee of the First Affiliated Hospital of Wenzhou Medical University (no. 2014005). We analyzed PRKCDBP expression level in the GEPIA website (http://gepia.cancer-pku.cn/index. html) and survival analysis of PRKCDBP in Kaplan-Meier plotter website (http://kmplot.com/analysis/index. php?).

Cell culture. BEAS-2B, A549, and A549/DDP cells were cultured in Roswell Park Memorial Institute (RPMI)-1640 medium containing $10 \%$ fetal bovine serum (FBS), in which a single-cell suspension was prepared by gentle pipetting in complete medium, and the cell suspension was transferred to a cell culture flask with a pipette and placed in an incubator at $37^{\circ} \mathrm{C}$, with $5 \% \mathrm{CO}_{2}$. A549/DDP was added to $2 \mu \mathrm{g} / \mathrm{ml}$ cisplatin to maintain drug resistance. When the cell growth status was satisfactory, the cell passage was performed at a confluency of $70-90 \%$.

$R T-q P C R$. Total RNA of tissues and cells was extracted using TRIzol ${ }^{\circledR}$ reagent (Invitrogen) and reverse-transcribed into cDNA using a PrimeScript RT Reagent kit (Takara), in accordance with the manufacturer's instructions. The reverse transcription reaction was carried out at $37^{\circ} \mathrm{C}$ for $15 \mathrm{~min}$ and the inactivation reaction of reverse transcriptase at $85^{\circ} \mathrm{C}$ for $5 \mathrm{sec}$. The levels of PRKCDBP, DNMT1, DNMT3a, tumor necrosis factor- $\alpha$ (TNF- $\alpha$ ) and $\beta$-actin were measured via Applied Biosystems 7500 Fast Real-Time PCR System (Thermo Fisher Scientific). The primer sequences used for PCR were: PRKCDBP, upstream: 5'-CAGGACACCGAGGAAGAT-3', downstream: 5'-TCAGGC TACACTCTCCATT-3'. DNMT1, upstream: 5'-AGGTGG AGAGTTATGACGAGGC-3', downstream: 5'-TCAGGCTAC ACTCTCCATT-3'. DNMT3a, upstream: 5'-CGGCCATAC GGTGGAGC-3', downstream: 5'-TATCGTGGTCTTTGG AGGCG-3'. TNF- $\alpha$ for upstream: 5'-TCCCCAGGGACCTCT CTCTA-3', downstream: 5'-GAGGGTTTGCTACAACAT GGG-3'. $\beta$-actin for upstream: 5'-CATGTACGTTGCTATCCA GGC-3', downstream: 5'-CTCCTTAATGTCACGCACGAT-3'. Then, $20 \mu \mathrm{l}$ PCR reaction volume was determined with $6 \mu \mathrm{l}$ double-distilled water, $10 \mu \mathrm{l}$ SYBR-Green I Premix mixture (2X, Takara), $1 \mu \mathrm{l}$ PCR forward primer (10 mM), $1 \mu 1 \mathrm{PCR}$ reverse primer $(10 \mathrm{mM})$ and $2 \mu \mathrm{l}$ cDNA template. The qPCR reaction program included a denaturation step of $10 \mathrm{~min}$ at $95^{\circ} \mathrm{C}$, followed by 40 cycles (for $5 \mathrm{sec}$ at $95^{\circ} \mathrm{C}$, and for $30 \mathrm{sec}$ at $60^{\circ} \mathrm{C}$ ), and a final extension step for $5 \mathrm{~min}$ at $72^{\circ} \mathrm{C}$. All samples were normalized to $\beta$-actin. The relative gene expression data were calculated using the median triplicate $(\Delta \mathrm{Cq}=\mathrm{Cq}$ median target gene-Cq median $\beta$-actin), and $2^{-\Delta \Delta \mathrm{Cq}}$ method (18).

Constructed lentivirus-mediated overexpression and siRNA vector. The overexpression vector targeted PRKCDBP (OE) as well as negative control vector (OE-NC)-transfected A549/DDP cells, overexpression vector targeted TNF- $\alpha$ (TNF- $\alpha$ OE) as well as negative control vector (TNF- $\alpha$ OE-NC)-transfected A549/DDP cells, and the overexpressed vector targeted DNMT1 (DNMT1 OE) and negative control vector (DNMT1 OE-NC) (Genechem)-transfected A549 cells. A549 cells were transfected with siRNA vector targeting TNF- $\alpha$ (TNF- $\alpha$ siRNA) and negative control siRNA (NC-siRNA) (TNF- $\alpha$ siRNA NC) (Genechem). Transfection was performed by seeding $2 \times 10^{5}$ cells into a six-well plate, and after $24 \mathrm{~h}$ the medium was aspirated and incubated at $37^{\circ} \mathrm{C}$ for 8-12 h with transfection complex (including vector and infection enhancer) according to the manufacturer's protocol and the MOI value (MOI=10) was calculated. The A549/DDP and A549 cells were infected with lentivirus for $72 \mathrm{~h}$ and treated with $2 \mu \mathrm{g} / \mathrm{ml}$ puromycin, and the overexpression efficiency was detected by RT-qPCR.

Decitabine processed A549/DDP cells. As a specific DNA methyltransferase inhibitor, decitabine can reverse the methylation process of DNA (19). After the cells were counted, 200,000 cells were seeded into 6-well plates. After $12 \mathrm{~h}$, the solution was changed and the drug was added: The final concentration of decitabine in the experimental group was $5 \mu \mathrm{M}$, and the cells were treated for $24 \mathrm{~h}$. 
A

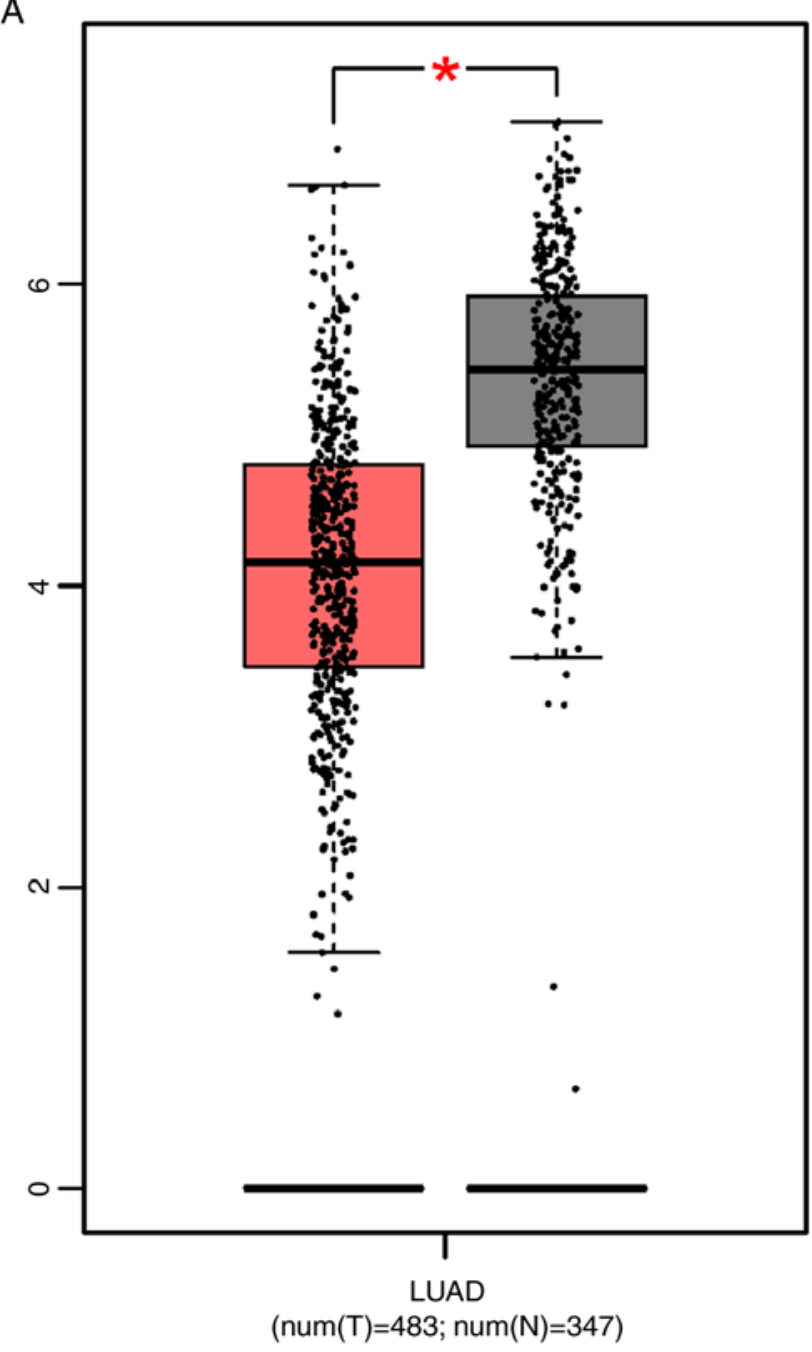

B

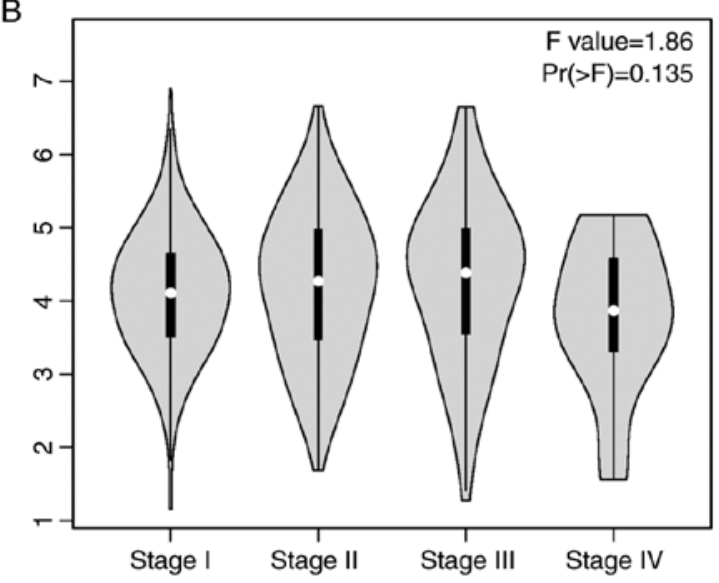

C

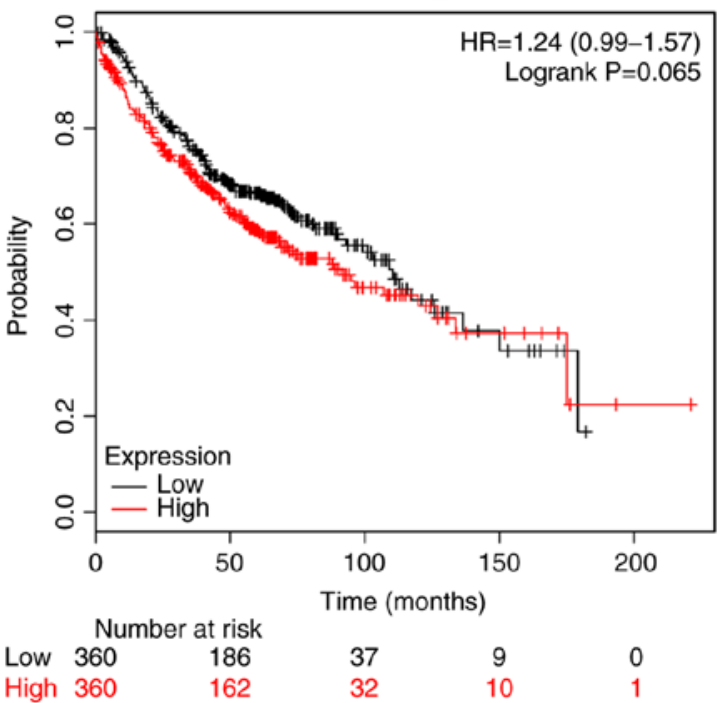

Figure 1. Expression level and survival analysis of PRKCDBP in LAD and adjacent tissues. (A) PRKCDBP expression level in LAD tissues was markedly lower than that in adjacent cancer tissues (http:/gepia.cancer-pku.cn/detail.php?gene=PRKCDBP, P<0.05). (B) The expression of PRKCDBP was not relevant with the histological differentiation ( $\mathrm{F}=1.86, \mathrm{P}=0.135$, http://gepia.cancer-pku.cn/detail.php?gene=PRKCDBP). (C) Survival analysis showed that $\mathrm{OS}$ of high expression level of PRKCDBP was not different from low expression level of PRKCDBP (HR=1.24, log-rank P=0.065), as shown by Kaplan-Meier plotter. ${ }^{*} \mathrm{P}<0.05$. $\mathrm{PRKCDBP}$, protein kinase $\mathrm{C}$ delta binding protein; $\mathrm{LAD}$, lung adenocarcinoma; OS, overall survival.

Cell migration assays. Migration assays were performed with $8.0-\mu \mathrm{m}$ pore inserts (Millipore) in a 24-well plate. For the migration assay, $2 \times 10^{4}$ cells with culture medium (without serum) were seeded into the upper compartment and RPMI- 1640 medium containing $10 \%$ FBS to the lower chamber of the Transwell inserts. Migrated cells were fixed with methanol and stained using $0.1 \%$ (w/v) crystal violet, then bleached with $33 \%$ acetic acid. Absorbance value was measured at $570 \mathrm{~nm}$ on a microplate reader. Each experiment was performed in triplicate.

Cell viability assay. Cell viability was evaluated by Cell Counting Kit-8 (CCK-8; Corning, Inc.) as per the manufacturer's instructions. Briefly, 3,000 cells were re-suspended and seeded into a 96-well plate supplemented in the presence of 10\% FBS and cultured for a week. The following day, the cells were incubated with CCK- 8 for $1 \mathrm{~h}$ at $37^{\circ} \mathrm{Cand}$ the absorbance was measured at $450 \mathrm{~nm}$ using a multifunctional microplate reader (Tecan).

Cisplatin sensitivity test. The cell inoculation density was 2,000 cells/well. After $24 \mathrm{~h}$ of cell attachment $100 \mu \mathrm{l}$ of complete medium (containing cisplatin) was added to each well. The concentration of cisplatin was 1,2,4,10 and $25 \mu \mathrm{g} / \mathrm{ml}$, and only the zeroing hole of the medium and the control hole of the single-cell suspension was set to zero. After $48 \mathrm{~h}$ of cultivation, the culture medium was replaced with complete medium containing $10 \%$ CCK8. The cultivation was for $45 \mathrm{~min}$. A microplate reader detected the absorbance at $450 \mathrm{~nm}$ wavelength, cell viability $\%=(\mathrm{A}$ plus-A blank)/(A0 plus drug-A blank) $\mathrm{x} 100 \%$, using the SPSS18.0 software profit regression model to calculate the IC50 of the cell.

Western blot detection of PRKCDBP. The loading volume of each sample was $30 \mu \mathrm{g}$, proteins from whole cell lysates were prepared in $1 \mathrm{X}$ sodium dodecyl sulfate buffer, separated by $10 \%$ sodium dodecyl sulfate-polyacrylamide gel electrophoresis (SDS-PAGE) and transferred to a PVDF (polyvinylidene difluoride) membrane (Millipore). The membranes were blocked with 5\% non-fat milk (RT, $1 \mathrm{~h}$ ) and incubated with respective primary antibodies (PRKCDBP, 16250-1-AP, 1:1,000; actin, HRP-60008, 1:4,000; $4^{\circ} \mathrm{C}$, overnight). Membranes were then 
A
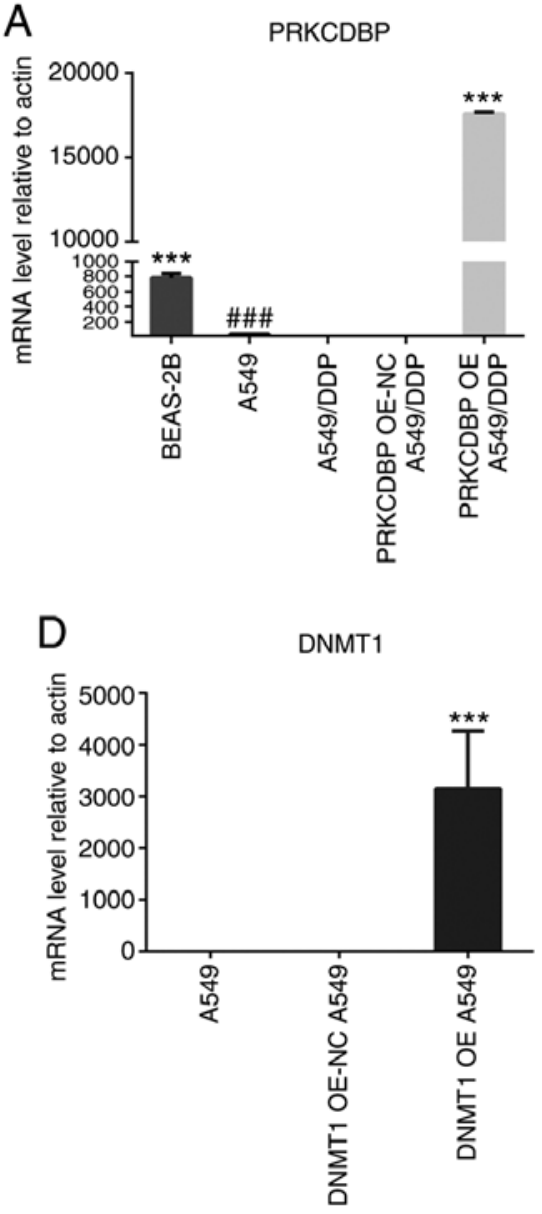

B
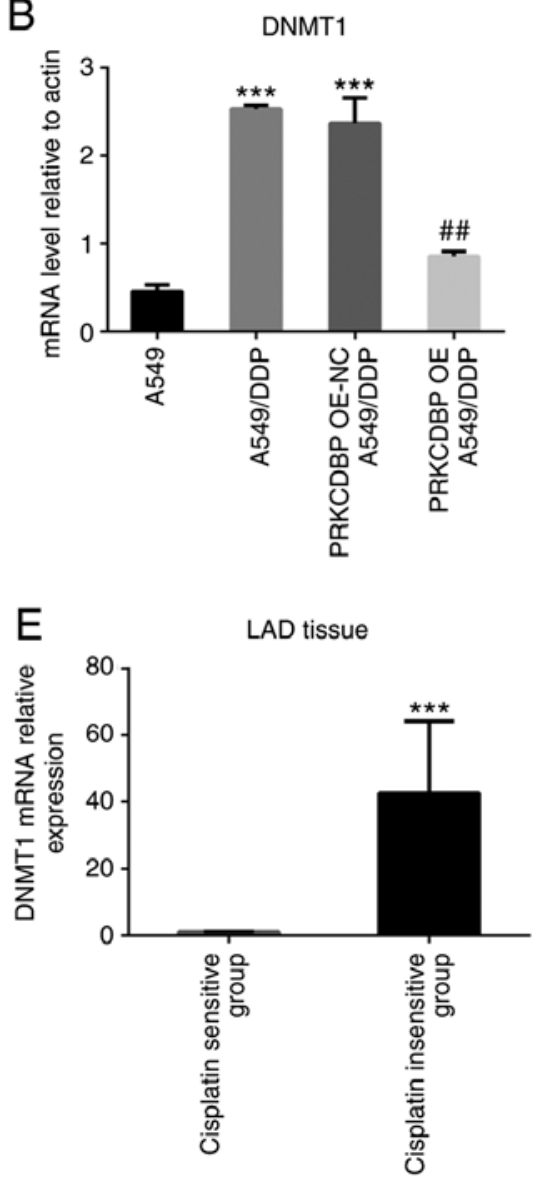

C

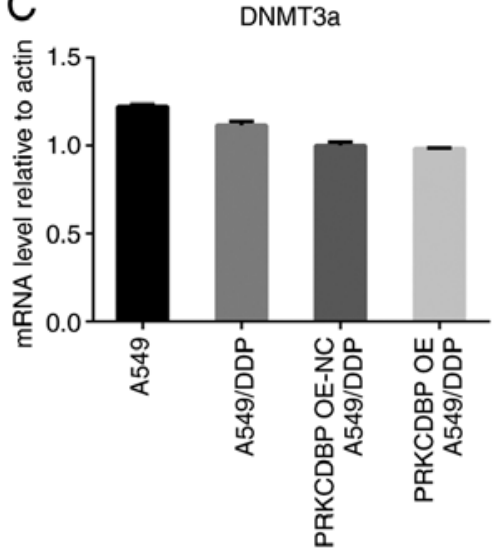

$\mathrm{F}$

F LAD tissue

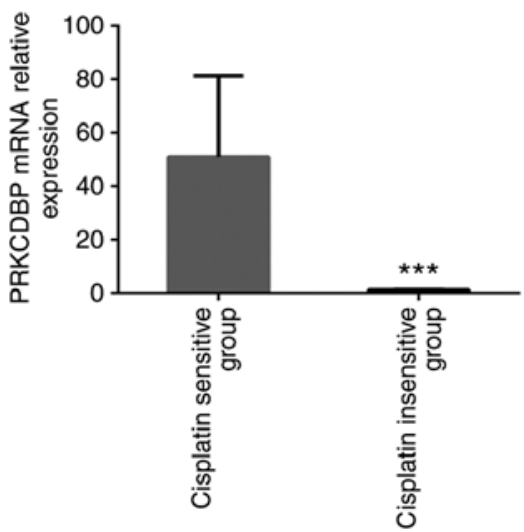

G
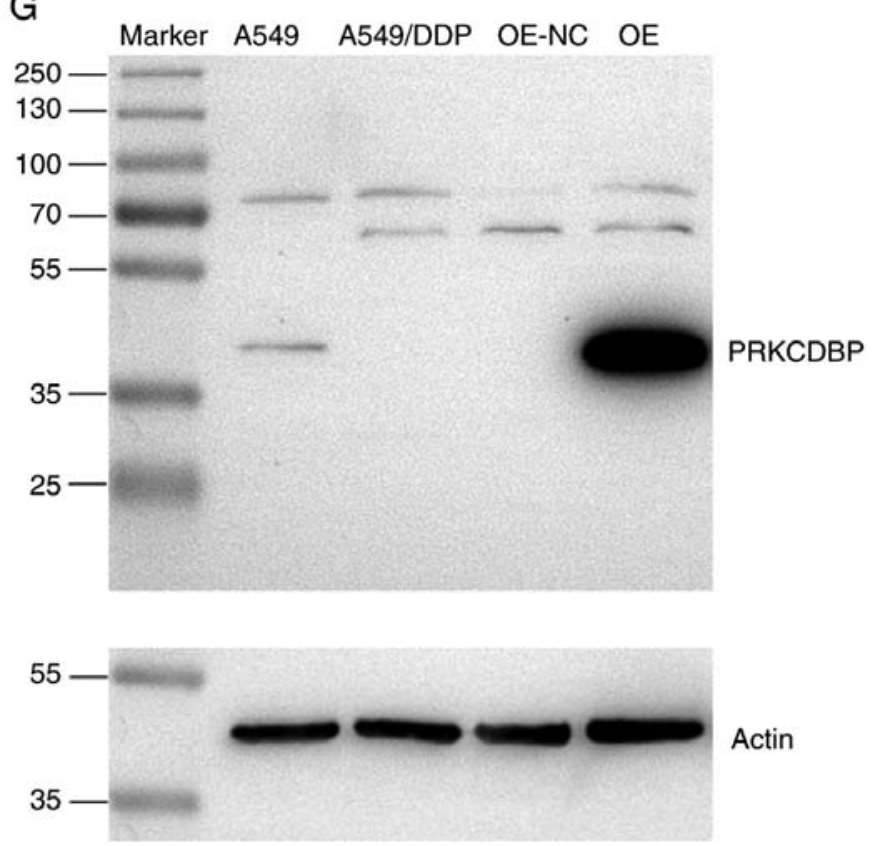

Figure 2. The expression level of PRKCDBP, DNMT1, DNMT3a from A549 and A549/DDP cells. (A) Compared to normal human bronchial epithelial cell line BEAS-2B, PRKCDBP mRNA level of A549 cells quickly decreased ( $\mathrm{t}=12.97, \mathrm{P}=0.0002)$. Compared to A549 cell, the expression levels of PRKCDBP mRNA level were signifantly reduced $(\mathrm{t}=115.3, \mathrm{P}<0.0001)$, After overexpression of PRKCDBP in A549/DDP cells, the expression level of PRKCDBP mRNA was signifantly increased compared to that of A549/DDP and A549/DDP NC ( $F=28326, \mathrm{P}<0.0001)$. (B) Compared to the A549/DDP NC group, DNMT1 mRNA level of PRKCDBP OE 549/DDP was clearly decreased ( $\mathrm{t}=5.127, \mathrm{P}=0.007)$. (C) DNMT3a mRNA level was not significantly different in A549/DDP cells $(\mathrm{t}=4.525, \mathrm{P}=0.110)$. (D) The expression levels of DNMT1 mRNA of OE group were markedly higher than that of A549 and A549 OE-NC $(\mathrm{F}=28326, \mathrm{P}<0.0001)$. (E) DNMT1 mRNA level in the cisplatin-insensitive group was markedly higher than that of the cisplatin-sensitive group $(t=7.233$, $P<0.0001)$. (F) $P R K C D B P$ mRNA level in the cisplatin-insensitive group was notably lower than that of cisplatin-sensitive group ( $\mathrm{t}=8.784, \mathrm{P}<0.0001)$. (G) Compared to A549 cells, the expression levels of PRKCDBP protein level were signifantly reduced in A549/DDP ( $\mathrm{P}<0.001)$, after overexpression of PRKCDBP in A549/DDP cells, the expression levels of PRKCDBP protein level were signifantly enhanced than that of A549/DDP and PRKCDBP OE-NC A549/DDP ( $F=28326, \mathrm{P}<0.0001$ ). ${ }^{\# \#} \mathrm{P}<0.01,{ }^{\# \# \#} \mathrm{P}<0.001,{ }^{* * *} \mathrm{P}<0.001$. $\mathrm{PRKCDBP}$, protein kinase $\mathrm{C}$ delta binding protein. 

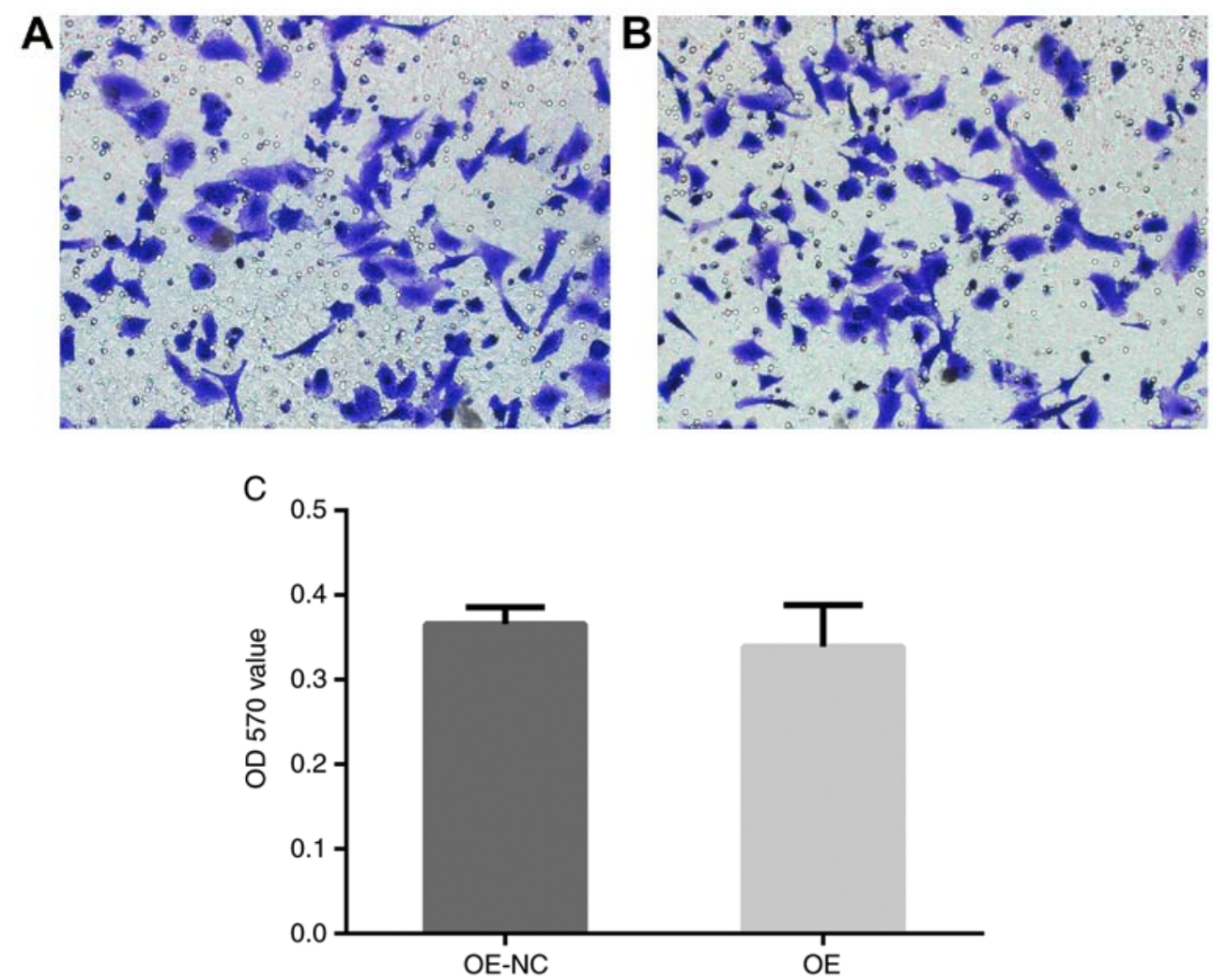

Figure 3. PRKCDBP was not relative to cell migration. (A) Cell migration experiment results of PRKCDBP OE A549/DDP group. (B) Cell migration experiment results of PRKCDBP OE NC A549/DDP group. (C) OD570 value of PRKCDBP OE A549/DDP group was silimar to that of PRKCDBP OE-NC A549/DDP group ( $\mathrm{t}=1.654, \mathrm{P}=0.213$ ). Thus, the cell migration ability of A549/DDP cell did not change after PRKCDBP was overexpressed. PRKCDBP, protein kinase $\mathrm{C}$ delta binding protein.

washed and incubated with horseradish peroxidase-conjugated secondary antibody (anti-rabbit IgG Sc-2004, 1:3,000; $4^{\circ} \mathrm{C}$, overnight). The size of PRKCDBP is $35-40 \mathrm{KDa}$, and the size of actin is $43 \mathrm{kDa}$. The signals were detected using ECL Plus kit. Gray value was measured with image $\mathrm{J}$.

Flow cytometry to detect apoptotic rate. A549 cells were inoculated in 6-well plates at a density of $1.0 \times 10^{6}$ cells/well. After various treatments for $48 \mathrm{~h}$, the cells were collected and digested with $0.25 \%$ trypsin at $37^{\circ} \mathrm{C}$ for $3-4 \mathrm{~min}$. The cells were gently pipetted and collected by centrifugation at $800 \mathrm{x}$ g for $5 \mathrm{~min}$ in room temperature. Then, the cells were washed twice with cold phosphate-buffered saline (PBS) and re-suspended in PBS prior to being stained with binding buffer. Added $1 \mathrm{ul}$ AnnexinV PE and mix well and reacted at room temperature in the dark for $15 \mathrm{~min}$. Then added $5 \mathrm{ul}$ 7-AAD dye solution, mixed well, and reacted at room temperature in the dark for $15 \mathrm{~min}$. Apoptosis was analyzed with a flow cytometer and the percentage of apoptotic cells was determined.

Cell cycle assay. The cells were harvested by centrifugation at $85 \mathrm{x} \mathrm{g}$ for $10 \mathrm{~min}$ in room temperature, fixed with $70 \%$ ethanol and incubated at $4^{\circ} \mathrm{C}$ overnight. The cells were resuspended with $400 \mu 1$ PBS (containing $2 \mathrm{mg} / \mathrm{ml}$ RNA enzymes) and incubated at $37^{\circ} \mathrm{C}$ for $30 \mathrm{~min}$, followed by the addition of $400 \mu \mathrm{l}$ propidium iodide $(0.1 \mathrm{mg} / \mathrm{ml})$ for $10 \mathrm{~min}$ and detection of DNA content by a flow cytometry analyzer (Cytomics FC 500; Beckman Coulter). The results were analyzed using MultiCycle software.
Bisulfite (BSP) sequencing PCR. i) Sulfite treatment and purification (Qiagen) as per the manufacturer's protocol, followed by $1 \mu \mathrm{g}$ of DNA for sulfite conversion, purification, and recovery. ii) Primer design (the underlined sequence is the area to be tested, and the thick black part base is the PCR primer position): CCAACACAGTCTCTGCGCCCACTAAGATGC ATGAAATAAAAATTTCCGTGACTCGCCCTTTGCAG TGGAGAACTGAAACAGGCACACCAGGGAATTGGAG CGGAGGAGGGTAACTCAAACTCAGAGTGAGAGGGT TTGCAGGGGGCCGATTTGGGGCCAACAGGCTTCCCA GCAGGCCCCCGGCGCGGGACAGCGGAAGGCGAA ACGCTTTCAAGAGACCCCGCTGCCAACATCCCCACG CCCTCGCGCCCTCCCGCCGCCCCAGAAGGCCAACT CCGCCTGCCTGAGTCACAGCTGGAGCTGGGGAGG AGCCAGgGAAAGGAGgCCCCTGACCGTAGTGCG GCCAGCA. PRKCDBP, upstream primer: 5'-TTTTTTGTA GTGGAGAATTGAAATAG-3', downstream primer: 5'-ATC AAAAACCTCCTTTCCCTAACT-3'. iii) PCR thermocycling conditions were: PCR system ( $30 \mu \mathrm{l})$, including $3 \mu \mathrm{l}$ 10X Taq buffer, $1 \mu \mathrm{l}$ dNTP, $1 \mu$ l enzyme, $1 \mu \mathrm{l} \mathrm{H}_{2} \mathrm{O}_{2}, 1 \mu \mathrm{l}$ upstream primer $(10 \mu \mathrm{M}), 1 \mu \mathrm{l}$ downstream primer $(10 \mu \mathrm{M}), 2 \mu \mathrm{l}$ template. Reaction conditions were: $95^{\circ} \mathrm{C} 10 \mathrm{~min}, 40$ cycles including $94^{\circ} \mathrm{C}$ for $30 \mathrm{sec}, 55^{\circ} \mathrm{C}$ for $30 \mathrm{sec}, 72^{\circ} \mathrm{C}$ for $40 \mathrm{sec}$. Finally, the extension was reacted at $72^{\circ} \mathrm{C}$ for $5 \mathrm{~min}$. iv) T/A cloning and sequencing. The target fragment was purified and XL10-Gold ${ }^{\circledR}$ ability, transformation, resuscitation and vaccination were carried out according to the manufacturer's protocol. Positive colonies were identified by enzyme digestion to identify the plasmid used for sequencing. 

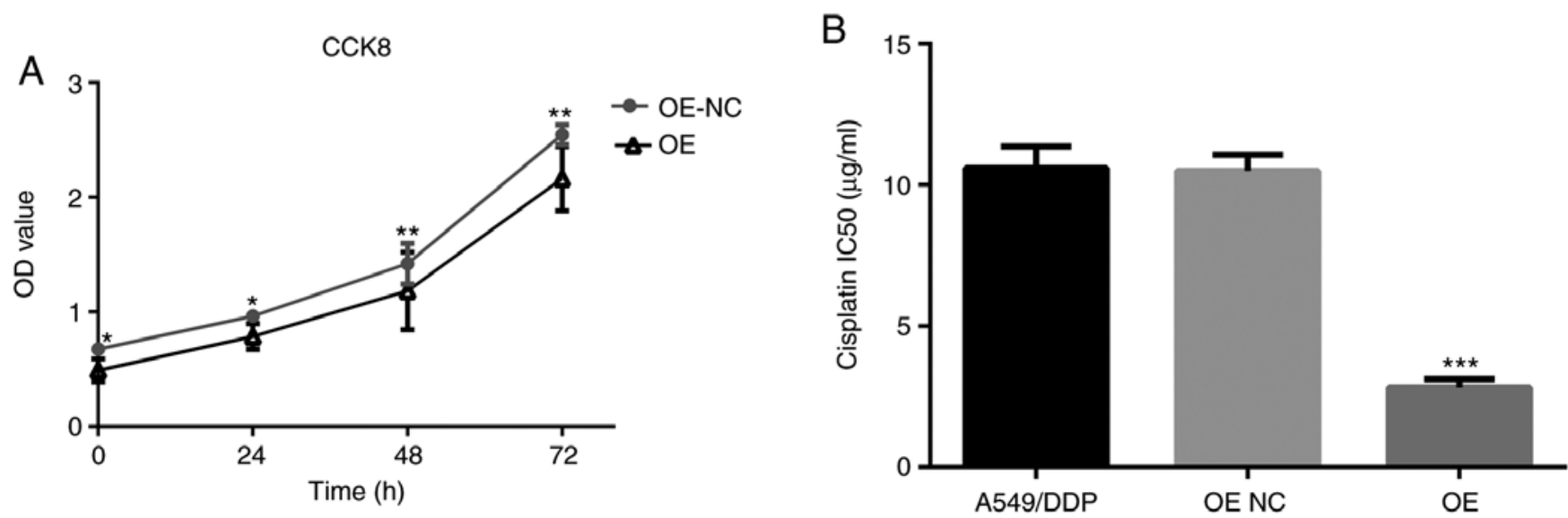

Figure 4. Overexpression of PRKCDBP inhibited cell proliferation and decreased IC50 in A549/DDP cells. (A and B) OD450 of PRKCDBP OE A549/DDP and PRKCDBP OE-NC A549/DDP groups gradually enhanced as time changes. Compared to PRKCDBP OE-NC A549/DDP group, the OD450 of PRKCDBP OE A549/DDP group clearly reduced in the $0 \mathrm{~h}(\mathrm{P}<0.05), 24 \mathrm{~h}(\mathrm{P}<0.05), 48 \mathrm{~h}(\mathrm{P}<0.01), 72 \mathrm{~h}(\mathrm{P}<0.01)$. The IC50 of cisplatin in PRKCDBP OE A549/DDP group $(5.98 \pm 1.20 \mu \mathrm{g} / \mathrm{ml})$ was lower than A549/DDP $(10.68 \pm 2.12 \mu \mathrm{g} / \mathrm{ml}, \mathrm{P}<0.001)$ and PRKCDBP OE-NC A549/DDP group (10.87 $\pm 2.21 \mu \mathrm{g} / \mathrm{ml}, \mathrm{P}<0.001) .{ }^{*} \mathrm{P}<0.05$, ${ }^{* *} \mathrm{P}<0.01,{ }^{* * *} \mathrm{P}<0.001$. $\mathrm{PRKCDBP}$, protein kinase $\mathrm{C}$ delta binding protein.
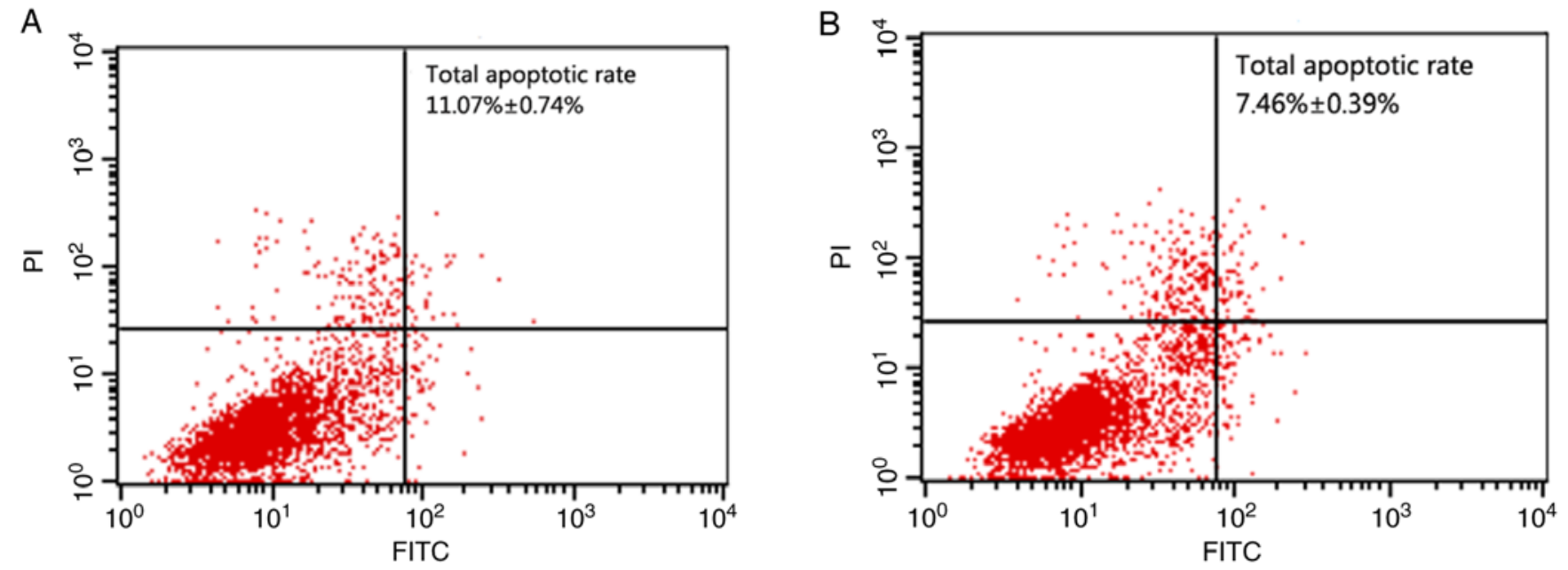

Figure 5. Overexpression of PRKCDBP promoted cell apoptosis. Apoptosis assay shown that (A) total apoptotic rate (11.07 $\pm 0.74 \%)$ in PRKCDBP OE A549/DDP group were distinctly higher than (B) that $(7.46 \pm 0.39 \%)$ of PRKCDBP OE-NC A549/DD group $(\mathrm{t}=8.652, \mathrm{P}<0.001)$ and it suggested overexpression of PRKCDBP promoted cell apoptosis. PRKCDBP, protein kinase $\mathrm{C}$ delta binding protein.

Statistical analysis. Differences in variables among groups were tested using one-way ANOVA with the least significant difference (LSD) test as the post hoc test for the normal distribution or Kruskal-Wallis test for the non-normal distribution. A comparison between the two groups was performed by the LSD test or Student's t-test or Mann-Whitney U test. Survival analysis is carried out using Kaplan-Meier and a log-rank test. $\mathrm{P}<0.05$ was considered statistically significant.

\section{Results}

Expression level and survival analysis of PRKCDBP in $L A D$ and adjacent tissues. According to GEPIA website, Kaplan-Meier plotter website, and Fig. 1, the expression level of PRKCDBP in LAD tissues was markedly lower than that in adjacent cancer tissues (http://gepia.cancer-pku. cn/detail.php?gene=PRKCDBP, $\mathrm{P}<0.05$; Fig. 1). The PRKCDBP expression level was not significant in the histological differentiation of lung cancer $(\mathrm{F}=1.86, \mathrm{P}=0.135)$. It was found that overall survival (OS) of high expression level of PRKCDBP was not significantly different from low expression level of PRKCDBP [hazard ratio $(\mathrm{HR})=1.24$, log-rank $\mathrm{P}=0.065$ ], as indicated by the Kaplan-Meier plotter (http://kmplot.com/analysis/index. php? $\mathrm{p}=$ service\&start=1) (Fig. 1A-C). DNMT1 mRNA level in the cisplatin-insensitive group was markedly higher than that of the cisplatin-sensitive group $(t=7.233, \mathrm{P}<0.0001$, Fig. $2 \mathrm{E})$ while PRKCDBP mRNA level in the cisplatin-insensitive group was notably lower than that of cisplatin-sensitive group $(\mathrm{t}=8.784$, $\mathrm{P}<0.0001$, Fig. 2F).

Expression levels of PRKCDBP, DNMT1, DNMT3a in A549 and A549/DDP cells. Compared with BEAS-2B cells, the PRKCDBP mRNA level in A549 cells was significantly decreased $(t=12.97, P=0.0002)$. Compared with A549 cells, the expression levels of PRKCDBP mRNA and protein levels were 

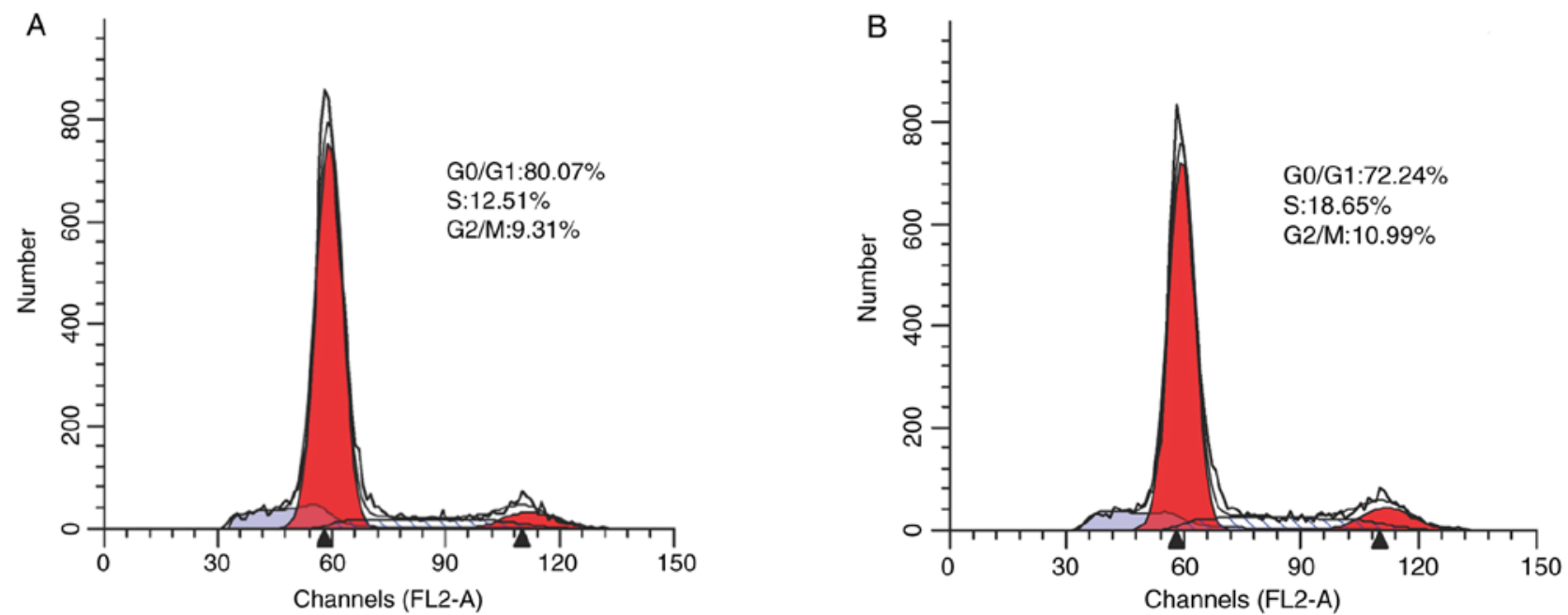

Figure 6. Result of cell cycle after overexpression of PRKCDBP. (A) Cells of G0/G1 phase $(80.07 \pm 2.4 \%)$ in the PRKCDBP OE A549/DDP group were significantly increased $(\mathrm{t}=22.147, \mathrm{P}<0.001)$ as compared to the (B) PRKCDBP OE-NC A549/DDP group $(72.24 \pm 2.1 \%)$, while those in the $\mathrm{S}(12.51 \pm 0.21 \%)$ and $\mathrm{G} 2 / \mathrm{M}(9.31 \pm 0.11 \%)$ phase were clearly decreased $(18.65 \pm 0.13$ and $10.99 \pm 0.12 \%)(\mathrm{t}=-4.15, \mathrm{P}<0.001$ and $\mathrm{t}=-8.02, \mathrm{P}<0.001)$. PRKCDBP, protein kinase $\mathrm{C}$ delta binding protein.
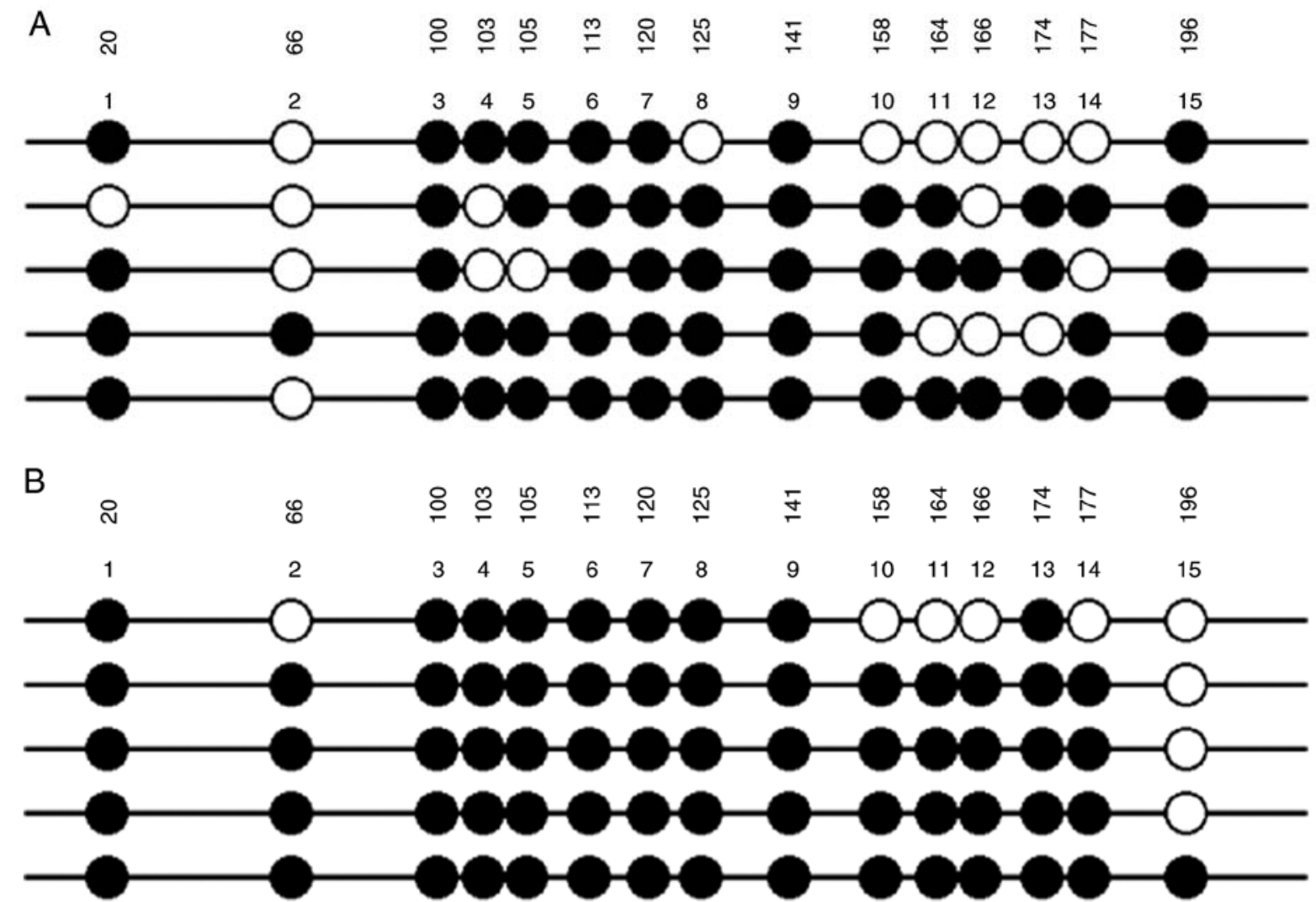

Figure 7. Methylation of PRKCDBP promoter. (A) A549/DDP, (B) A549 cells. Black circle, methylation. The results of BSP showed that the degree of methylation of PRKCDBP promoter in A549/DDP cells (66/75) was distinctly higher than that in A549 cells (56/75) (Table I). PRKCDBP, protein kinase C delta binding protein.

markedly reduced (t=115.3, $\mathrm{P}<0.0001$ ) (Fig. 2A, D and G), while the DNMT1 mRNA level was markedly elevated in A549/DDP cell line ( $\mathrm{t}=10.413, \mathrm{P}<0.001)$ (Fig. 2B). By contrast, DNMT3a mRNA level was not significantly different in the A549/DDP cell line ( $\mathrm{t}=4.525, \mathrm{P}=0.110)$ (Fig. 2C). After overexpression of PRKCDBP in A549/DDP cells, PRKCDBP mRNA and protein levels were notably increased compared with A549/DDP and A549/DDP NC ( $\mathrm{F}=28326, \mathrm{P}<0.0001)$ (Fig. 2A and E). Similarly, DNMT1 mRNA level in DNMT1 OE A549 group was significantly higher than that of A549 and DNMT1 OE A549 NC ( $\mathrm{F}=28326, \mathrm{P}<0.0001)$ (Fig. 2D), which indicated successful establishment of a lentiviral vectormediated overexpression of PRKCDBP in the A549/DDP group and overexpression of DNMT1 in the A549 group. Compared 
A

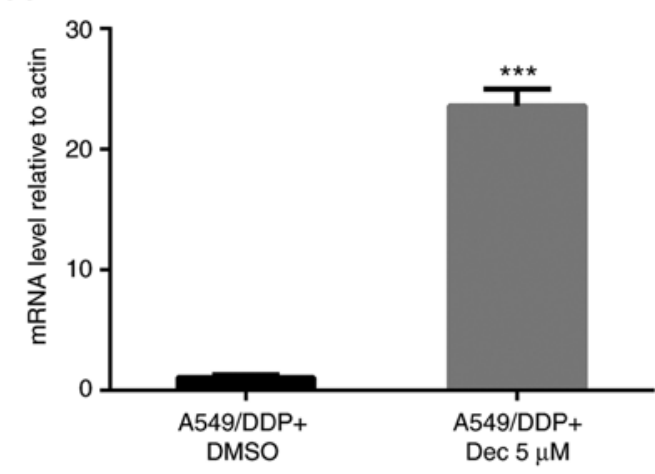

B

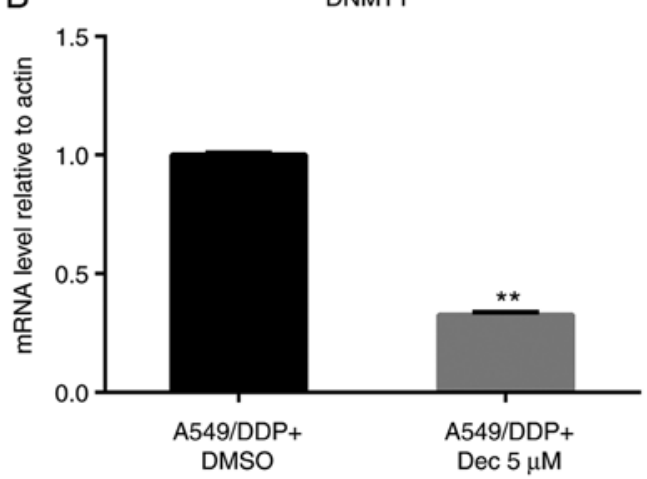

Figure 8. Relative genes change after $5 \mu \mathrm{M}$ decitabine. (A) Expression of PRKCDBP mRNA was obviously increased after treatment with $5 \mu \mathrm{M}$ decitabine for $24 \mathrm{~h}(\mathrm{t}=16.00, \mathrm{P}<0.0001)$, (B) while the level of DNMT1 mRNA was significantly reduced $(\mathrm{t}=48.422, \mathrm{P}<0.001) .{ }^{* *} \mathrm{P}<0.01,{ }^{* * *} \mathrm{P}<0.001$. $\mathrm{PRKCDBP}$, protein kinase $\mathrm{C}$ delta binding protein.

to A549/DDP NC group, DNMT1 mRNA level was markedly decreased ( $\mathrm{t}=5.127, \mathrm{P}=0.007)$ (Fig. 2B), while DNMT3a mRNA level did not significantly change in PRKCDBP OE A549/DDP group ( $t=0.849, \mathrm{P}=0.444)$ (Fig. 2B). Due to the low expression level of PRKCDBP in LAD tissues and A549 cells, DNMT1 mRNA level in the A549/DDP cell line was markedly elevated, suggesting that PRKCDBP may be a hypermethylation state in A549/DDP cell line by DNMT1.

PRKCDBP was not relative to cell migration. There was no significant difference in the OD570 value between PRKCDBP OE A549/DDP group and PRKCDBP OE A549/DDP NC group ( $\mathrm{t}=1.654, \mathrm{P}=0.213$ ) (Fig. 3). This highlighted that overexpression of PRKCDBP did not influence the migration ability of A549/DDP cell line.

Overexpression of PRKCDBP inhibited cell proliferation and reduced IC50 in the A549/DDP cell line. Compared with the PRKCDBP OE-NC A549/DDP group, OD450 in the PRKCDBP OE A549/DDP group was markedly reduced at $0(\mathrm{P}<0.05), 24(\mathrm{P}<0.05), 48(\mathrm{P}<0.01)$, and $72 \mathrm{~h}(\mathrm{P}<0.01)$ (Fig. 4A). The IC50 of cisplatin in the PRKCDBP OE A549/DDP group $(5.98 \pm 1.20 \mu \mathrm{g} / \mathrm{ml})$ was lower than that in the A549/DDP $(10.68 \pm 2.12 \mu \mathrm{g} / \mathrm{ml}, \mathrm{P}<0.001)$ and PRKCDBP OE-NC group $(10.87 \pm 2.21 \mu \mathrm{g} / \mathrm{ml}, \mathrm{P}<0.001)$ (Fig. 4B).

Overexpression of PRKCDBP promoted cell apoptosis. Flow cytometry showed an apoptotic rate of $11.07 \pm 0.74 \%$ 

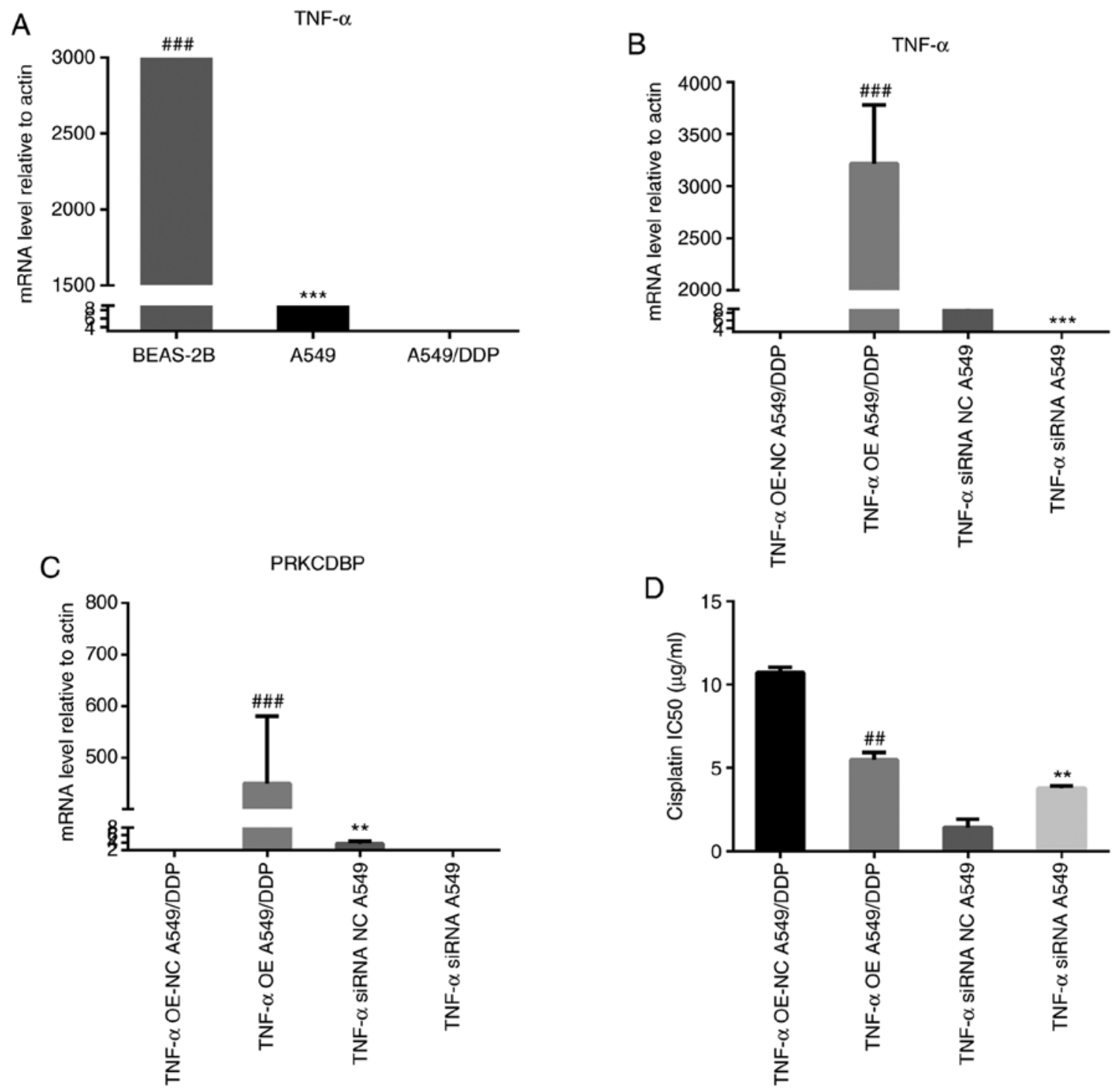

Figure 9. TNF- $\alpha$ regulated PRKCDBP to influence cisplatin resistance in LAD. (A) The TNF- $\alpha$ mRNA level in A549/DDP was less than that in A549 cells $(\mathrm{t}=41.52, \mathrm{P}<0.0001)$ and BEAS-2B $(\mathrm{t}=42.50, \mathrm{P}<0.0001)$. (B) Lentivirus-mediated TNF- $\alpha$ overexpression and siRNA vector transfection cells was established. (C) After TNF- $\alpha$ was overexpressed, PRKCDBP mRNA expression level was increased ( $t=5.977, \mathrm{P}=0.004$ ) in A549/DDP. After TNF- $\alpha$ was knocked down, the PRKCDBP mRNA expression level was reduced $(\mathrm{t}=7.878, \mathrm{P}=0.001)$ and in A549. (D) After TNF- $\alpha$ was overexpressed, IC50 was decreased (IC=10.6 \pm 0.4 vs. $5.4 \pm 0.2 \mu \mathrm{g} / \mathrm{ml}, \mathrm{t}=6.34, \mathrm{P}=0.002)$ in A549/DDP. After TNF- $\alpha$ was knocked down, IC50 was increased $(\mathrm{IC}=1.4 \pm 0.1 \mathrm{vs} .3 .7 \pm 0.2 \mu \mathrm{g} / \mathrm{ml}, \mathrm{t}=10.45, \mathrm{P}=0.007)$ in A549. ${ }^{\# /} \mathrm{P}<0.01,{ }^{\# \# \#} \mathrm{P}<0.001,{ }^{* *} \mathrm{P}<0.01,{ }^{* * *} \mathrm{P}<0.001$. TNF, tumor necrosis factor; $\mathrm{PRKCDBP}$, protein kinase $\mathrm{C}$ delta binding protein.

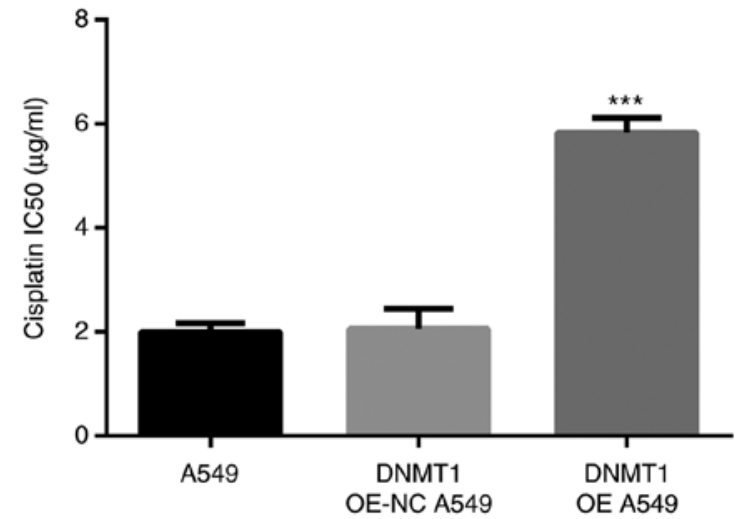

Figure 10. Overexpression of DNMT1 improved IC50 in A549 cells. The IC50 of cisplatin in DNMT1 OE A549 group $(5.83 \pm 0.18 \mu \mathrm{g} / \mathrm{ml})$ was higher than A549 $(1.99 \pm 0.10 \mu \mathrm{g} / \mathrm{ml}, \mathrm{P}<0.001)$ and DNMT1 OE-NC A549 group $(2.06 \pm 0.22 \mu \mathrm{g} / \mathrm{ml}, \mathrm{P}<0.001)$. Thus, overexpression of DNMT1 improved the IC50 of cisplatin in A549 cells and increased cisplatin resistance. ${ }^{* * * *} \mathrm{P}<0.001$. in the PRKCDBP OE A549/DDP group was significantly higher than that of $7.46 \pm 0.39 \%$ in the PRKCDBP OE-NC A549/DDP group ( $\mathrm{t}=8.652, \mathrm{P}<0.001)$, which demonstrated that overexpression of PRKCDBP promoted cell apoptosis (Fig. 5). Additionally, the cells in G0/G1 phase $(80.07 \pm 2.4 \%)$ in the PRKCDBP OE A549/DDP group were significantly increased $(\mathrm{t}=22.147, \mathrm{P}<0.001)$, compared with those in the PRKCDBP OE-NC A549/DDP group $(72.24 \pm 2.1 \%)$, while those in the S $(12.51 \pm 0.21 \%)$ and $\mathrm{G} 2 / \mathrm{M}(9.31 \pm 0.11 \%)$ phases were markedly declined $(18.65 \pm 0.13$ and $10.99 \pm 0.12 \%)(\mathrm{t}=-4.15, \mathrm{P}<0.001$; $\mathrm{t}=-8.02, \mathrm{P}<0.001)$. The results of the cell cycle assay further confirmed that overexpression of PRKCDBP inhibited the proliferation ability of A549/DDP cell line (Fig. 6).

Results of DNA methylation. As shown in Fig. 7, the degree of methylation of PRKCDBP in A549/DDP cell line (66/75) was markedly higher than that in A549 cells (56/75) 
(Table I). Therefore, DNA methylation was caused by DNA methyltransferase DNMT1, resulting in hypermethylation of PRKCDBP promoter in A549/DDP cells and reduction of PRKCDBP mRNA and protein levels. Further studies showed that PRKCDBP mRNA level was notably elevated with $5 \mu \mathrm{M}$ decitabine for $24 \mathrm{~h}(\mathrm{t}=16.00, \mathrm{P}<0.0001)$, while the DNMT1 mRNA level was significantly decreased $(\mathrm{t}=48.422, \mathrm{P}<0.0001)$ (Fig. 8). Therefore, decitabine is a specific DNA methyltransferase inhibitor that can inhibit the DNMT1 mRNA level, thereby inhibiting the methylation of PRKCDBP, leading to an increase in the PRKCDBP mRNA level.

TNF- $\alpha$ regulated PRKCDBP to influence cisplatin resistance in $L A D$. We compared the PRKCDBP OE A549/DDP group and the PRKCDBP NC A549/DDP group by mRNA expression profiling, and it was found that TNF- $\alpha$ could regulate PRKCDBP. Our findings revealed that the TNF- $\alpha$ mRNA level in A549/DDP cell line was lower than in A549 cells $(\mathrm{t}=41.52, \mathrm{P}<0.0001)$ and BEAS-2B $(\mathrm{t}=42.50, \mathrm{P}<0.0001)$ (Fig. 9A). Lentiviral vector-mediated overexpression of TNF- $\alpha$ A549/DDP and siRNA vector transfection of A549 cell line (Fig. 9B) was established. After TNF- $\alpha$ was overexpressed, PRKCDBP mRNA level was elevated $(\mathrm{t}=5.977$, $\mathrm{P}=0.004$, Fig. 9C), and IC50 was reduced (10.6 \pm 0.4 vs. $5.4 \pm 0.2 \mu \mathrm{g} / \mathrm{ml}, \mathrm{t}=6.34, \mathrm{P}=0.002$, Fig. 9D) in A549/DDP. After TNF- $\alpha$ was knocked down, PRKCDBP mRNA level was reduced $(\mathrm{t}=7.878, \mathrm{P}=0.001$, Fig. $9 \mathrm{C})$ and $\mathrm{IC} 50$ was increased $(1.4 \pm 0.1$ vs. $3.7 \pm 0.2 \mu \mathrm{g} / \mathrm{ml}, \mathrm{t}=10.45, \mathrm{P}=0.007$, Fig. 9D) in A549 cells. Thus, we speculated that TNF- $\alpha$ could regulate PRKCDBP expression level to influence cisplatin resistance in LAD.

Overexpression of DNMT1 improved IC50 in A549 cells. The IC50 of cisplatin in DNMT1 OE A549 group $(5.83 \pm 0.18 \mu \mathrm{g} / \mathrm{ml})$ was markedly higher than that in A549 cells $(1.99 \pm 0.10 \mu \mathrm{g} / \mathrm{ml}$, $\mathrm{P}<0.001)$ and DNMT1 OE-NC A549 group $(2.06 \pm 0.22 \mu \mathrm{g} / \mathrm{ml}$, $\mathrm{P}<0.001$ ) (Fig. 10). Therefore, overexpression of DNMT1 improved the IC50 of cisplatin in A549 cells and increased cisplatin resistance.

\section{Discussion}

Cisplatin exerts anticancer effects via multiple mechanisms, yet its most prominent (and best understood) mode of action involves the generation of DNA lesions followed by activation of the DNA damage response and the induction of mitochondrial apoptosis. Despite a consistent rate of initial responses, cisplatin treatment often results in the development of chemoresistance, leading to therapeutic failure (8-12). Cisplatin resistance arises through a multifactorial mechanism involving reduced drug uptake, increased drug inactivation, increased DNA damage repair, and inhibition of transmission of DNA damage recognition signals to the apoptotic pathway, such as P53 pathway.

In the current study, our findings showed that PRKCDBP level was markedly decreased in LAD tissues and A549/DDP cell line compared to the adjacent cancer tissues and A549 cells, while the DNMT1 mRNA level was significantly elevated. In addition, the promoter of PRKCDBP was hypermethylated in A549/DDP. DNMT1 mRNA level in cisplatin-insensitive group was markedly higher than that in cisplatin-sensitive group while PRKCDBP mRNA expression level in cisplatin-insensitive group was notably lower than that in cisplatin-sensitive group. Compared with the PRKCDBP NC A549/DDP group, the DNMT1 mRNA level was significantly reduced. Further investigation showed that PRKCDBP mRNA level was significantly elevated after treatment with $5 \mu \mathrm{M}$ decitabine for $24 \mathrm{~h}$, while DNMT1 mRNA level was markedly decreased. The above-mentioned findings revealed that PRKCDBP is a tumor suppressor gene and the promoter of PRKCDBP was hypermethylated in A549/DDP cell line by DNMT1.

After PRKCDBP was overexpressed, cell proliferation, $\mathrm{S}$ phase and $\mathrm{G} 2 / \mathrm{M}$ phase cells were notably reduced. By contrast, apoptosis ability, G0/G1 phase cells and IC50 of cisplatin were significantly elevated, although the migration ability did not markedly change. We compared the PRKCDBP OE A549/DDP group and the PRKCDBP NC A549/DDP group by mRNA expression profiling, and it was found that TNF- $\alpha$ could regulate PRKCDBP. These results are consistent with some literature reports $(17,20,21)$. TNF- $\alpha$ resulted in an increase of the PRKCDBP mRNA level, while TNF- $\alpha$ siRNA led to a decrease thereof $(\mathrm{P}<0.001)$. These findings demonstrated that low PRKCDBP could increase the proliferation ability and IC50 of cisplatin. TNF- $\alpha$ appeared to regulate PRKCDBP mRNA level to affect cisplatin resistance in LAD. Overexpression of DNMT1 improved the IC50 of cisplatin in A549 cells and increased cisplatin resistance.

In summary, results of the present study showed that the promoter of PRKCDBP was hypermethylated in A549/DDP. Low expression level of PRKCDBP could promote cisplatin resistance in LAD by DNMT1 and TNF- $\alpha$.

\section{Acknowledgements}

Not applicable.

\section{Funding}

This study was financially supported by the National Natural Science Foundation of China (81672088), Zhejiang Provincial Natural Science Foundation (LY19H200002), Zhejiang Provincial Health Planning Commission (2018KY514), the Wenzhou Municipal Science and Technology Bureau of China (Y20170208, Y20170718), and Zhejiang University Student Science and Technology Innovation Activity Plan (New Miao Talent Plan, 2020R413082).

\section{Availability of data and materials}

All data generated or analyzed during this study are included in this published article.

\section{Authors' contributions}

JF, HZ and YW made substantial contributions to the design of the study. JF and JC analyzed and interpreted the patient data. JF, HZ, JC and YW performed the cell biological experiments. All authors contributed to writing the manuscript. All authors have read and approved the final manuscript. 


\section{Ethics approval and consent to participate}

The study was approved by the Institutional Ethics Review Committee of the First Affiliated Hospital of Wenzhou Medical University. Patient consent was obtained.

\section{Patient consent for publication}

Not applicable.

\section{Competing interests}

The authors declare that they have no competing interests.

\section{References}

1. Bray F, Ferlay J, Soerjomataram I, Siegel RL, Torre LA and Jemal A: Global cancer statistics 2018: GLOBOCAN estimates of incidence and mortality worldwide for 36 cancers in 185 countries. CA Cancer J Clin 68: 394-424, 2018.

2. Herbst RS, Morgensztern D and Boshoff C: The biology and management of non-small cell lung cancer. Nature 553: 446-454, 2018.

3. Pignon JP, Tribodet H, Scagliotti GV, Douillard JY, Shepherd FA, Stephens RJ, Dunant A, Torri V, Rosell R, Seymour L, et al: Lung adjuvant cisplatin evaluation: A pooled analysis by the LACE Collaborative Group. J Clin Oncol 26: 3552-3559, 2008.

4. Zarogoulidis K, Zarogoulidis P, Darwiche K, Boutsikou E, Machairiotis N, Tsakiridis K, Katsikogiannis N, Kougioumtzi I, Karapantzos I, Huang H and Spyratos D: Treatment of non-smal cell lung cancer (NSCLC). J Thorac Dis 5 (Suppl 4): S389-S396, 2013.

5. Bunn PA Jr and Kelly K: New combinations in the treatment of lung cancer: A time for optimism. Chest 117 (4 Suppl 1): 138S-143S, 2000.

6. Spiro SG and Silvestri GA: One hundred years of lung cancer. Am J Respir Crit Care Med 172: 523-529, 2005.

7. Choi MK and Kim DD: Platinum transporters and drug resistance. Arch Pharm Res 29: 1067-1073, 2006.

8. Martin LP, Hamilton TC and Schilder RJ: Platinum resistance: The role of DNA repair pathways. Clin Cancer Res 14: 1291-1295, 2008.

9. Wangpaichitr M, Wu C, You M, Kuo MT, Feun L, Lampidis T and Savaraj N: Inhibition of mTOR restores cisplatin sensitivity through down-regulation of growth and anti-apoptotic proteins. Eur J Pharmacol 591: 124-127, 2008.
10. Seve P and Dumontet C: Chemoresistance in non-small cell lung cancer. Curr Med Chem Anticancer Agents 5: 73-88, 2005.

11. Ohmichi M, Hayakawa J, Tasaka K, Kurachi H and Murata Y: Mechanisms of platinum drug resistance. Trends Pharmacol Sci 26: 113-116, 2005.

12. Wu C, Wangpaichitr M, Feun L, Kuo MT, Robles C, Lampidis T and Savaraj N: Overcoming cisplatin resistance by mTOR inhibitor in lung cancer. Mol Cancer 4: 25, 2005.

13. Hu L, Chen J, Zhang F, Wang J, Pan J, Chen J and Wang Y: Aberrant long noncoding RNAs expression profiles affect cisplatin resistance in lung adenocarcinoma. Biomed Res Int 2017: $7498151,2017$.

14. Li Y, Melnikov AA, Levenson V, Guerra E, Simeone P, Alberti S and Deng Y: A seven-gene CpG-island methylation panel predicts breast cancer progression. BMC cancer 15: 417, 2015.

15. Fukasawa M, Kimura M, Morita S, Matsubara K, Yamanaka S, Endo C, Sakurada A, Sato M, Kondo T, Horii A, et al: Microarray analysis of promoter methylation in lung cancers. J Hum Genet 51: 368-374, 2006.

16. Moutinho C, Martinez-Cardus A, Santos C, Navarro-Pérez V, Martínez-Balibrea E, Musulen E, Carmona FJ, Sartore-Bianchi A, Cassingena A, Siena S, et al: Epigenetic inactivation of the BRCA1 interactor SRBC and resistance to oxaliplatin in colorectal cancer. J Natl Cancer Inst 106: djt322, 2014.

17. Lee JH, Kang MJ, Han HY, Lee MG, Jeong SI, Ryu BK, Ha TK, Her NG, Han J, Park SJ, et al: Epigenetic alteration of PRKCDBP in colorectal cancers and its implication in tumor cell resistance to $\mathrm{TNF} \alpha-$-induced apoptosis. Clin Cancer Res 17: 7551-7562, 2011.

18. Livak KJ and Schmittgen TD: Analysis of relative gene expression data using real-time quantitative PCR and the 2(-Delta Delta C(T)) method. Methods 25: 402-408, 2001.

19. Yilmaz A, Menevse S, Konac E and Alp E: The DNA methyl transferase inhibitor, 5'-aza-2-deoxycitidine, enhances the apoptotic effect of Mevastatin in human leukemia HL-60 cells. Hum Exp Toxicol 33: 414-423, 2014.

20. Kim JW, Lee CK, Kim HJ, Shim JJ, Jang JY, Dong SH, Kim BH, Chang YW and Chi SG: Polymorphisms in PRKCDBP, a transcriptional target of TNF- $\alpha$, Are associated with inflammatory bowel disease in Korean. Intest Res 13: 242-249, 2015.

21. Kim JW, Kim HJ, Lee CK, Shim JJ, Jang JY, Dong SH, Kim BH, Chang YW and Chi SG: Elevation of PRKCDBP, a novel transcriptional target of TNF- $\alpha$, and its downregulation by infliximab in patients with ulcerative colitis. Dig Dis Sci 59: 2947-2957, 2014.

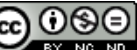

This work is licensed under a Creative Commons Attribution-NonCommercial-NoDerivatives 4.0 International (CC BY-NC-ND 4.0) License. 